\title{
HUBUNGAN DISIPLIN KERJA DAN MOTIVASI TERHADAP BUDAYA KERJA PADA CV. PANCA MANDIRI JAYA KARAWANG
}

\author{
Asep Jamaludin \\ Program Studi Manajemen, Fakultas Bisnis dan Ilmu Sosial \\ Universitas Buana Perjuangan Karawang \\ Email : asepjamaludin@ubpkarawang.ac.id
}

\begin{abstract}
ABSTRAK
Penelitian ini bertujuan untuk mengetahui apakah Motivasi dan Disiplin Kerja berHubungan terhadap Budaya Kerja Pegawai CV. Panca Mandiri Jaya Karawang. dan apakah secara simultan Motivasi dan Disiplin Kerja berHubungan positif terhadap Budaya Kerja Pegawai CV. Panca Mandiri Jaya Karawang. Penelitian ini dilakukan dengan menggunakan metode deskriptif kuantitatif dan verifikatif, yaitu mengumpulkan, menyajikan, menganalisis, dan melakukan pengujian hipotesis, serta membuat kesimpulan dan saran. Sempel dikumpilkan dengan metode proportionate stratified Random Sampling dengan jumlah sempel 146 responden dari populasi 230 Pegawai. Teknik pengumpulan data adalah melalui angket dan observasi. Untuk melihat Hubungan maka analisis yang digunakan adalah path analisis. Sehingga dari hasil penelitian akan diketahui secara parsial variabel Motivasi dan Disiplin Kerja mempunyai Hubungan yang signifikan terhadap Budaya Kerja Pegawai. Hasil Penelitian ini dapat disiimpulkan bahwa terdapat Hubungan dari Motivasi dan Disiplin Kerja terhadap Budaya Kerja Pegawai dengan rincian sebagai berikut :

a. Terdapat Hubungan Parsial Motivasi terhadap Budaya Kerja CV. . Panca Mandiri Jaya Karawang. dengan nilai $\operatorname{sig}(0,000)<\alpha(0,05)$ dan $t_{\text {hitung }}(17,266)$ $>t_{\text {tabel }}(1,655)$, maka " $\mathrm{H}_{0}$ ditolak $\mathrm{Hal}$ ini menunjukkan bahwan motivasi berhubungan positif. Motivasi memiliki kontribusi sebesar 51,7\% terhadap Budaya Kerja Pegawai

b. Terdapat Hubungan Parsial Disipin Kerja terhadap Budaya Kerja CV. Panca Mandiri Jaya Karawang. dengan nilai sig $(0,000)<\alpha(0,05)$ dan thitung $(14,104)$ $>t_{\text {tabel }}(1,655)$, maka " $\mathrm{H}_{0}$ ditolak Hal ini menunjukkan bahwa Disiplin Kerja berHubungan positif”. Disiplin Kerja memiliki kontribusi sebesar 409\% terhadap Budaya Kerja.

Terdapat Hubungan simultan dari Motivasi dan Disiplin Kerja terhadap Budaya Kerja dengan kriteria nilai uji nilai $\operatorname{sig}(0,000)<\alpha(0,05)$ dan $f_{\text {hitung }}(883 \mathrm{~K} 317)>$ $t_{\text {tabel }}(3,91)$, maka $\mathrm{H}_{0}$ ditolak. Total Pengauh Motivasi $\left(\mathrm{X}_{1}\right)$ dan Disiplin Kerja $\left(\mathrm{X}_{2}\right)$ memiliki kontribusi terhadap Budaya Kerja (Y) sebesar 92,5\% sedangkan sisanya $7,5 \%$ merupakan kontribusi variabel lain $(\varepsilon)$ yang tidak diteliti. Hal ini menunjukan
\end{abstract}


bahwa motivasi dan Disiplin kerja secara bersama-sama memiliki Hubungan terhadap Budaya Kerja Pegawai CV. Panca Mandiri Jaya Karawang.

\title{
Kata Kunci : Motivasi, Disiplin Kerja, Budaya Kerja Pegawai
}

\begin{abstract}
This study aims to determine whether Work Motivation and Discipline play a role on CV Employee Commitments. Panca Mandiri Jaya Karawang. and whether the Motivation and Work Discipline simultaneously on Employee Commitment CV. Panca Mandiri Jaya Karawang. This research was conducted using quantitative descriptive and verification methods, namely collecting, presenting, analyzing, and testing hypotheses, and making conclusions and suggestions. The samples were collected using the proportional stratified random sampling method with a total of 146 respondents from a population of 230 employees. Data collection techniques are through questionnaires and observations. To see the difference, the analysis used is path analysis. Motivation and Work Discipline variables have a significant influence on Employee Commitment. The results of this study can be concluded that there is an effect of motivation and work discipline on employee commitment (with details as follows:

a. Regarding the Effect of Partial Motivation on CV Commitments. . Panca Mandiri Jaya Karawang. with $\operatorname{sig}(0,000)<\alpha(0,05)$ and t count $(17,266)>$ ttable $(1,655)$, then $\mathrm{H} 0$ denies This shows that positive motivation is positive motivation.

b. Related to Partial Influence Disipin Work on CV Commitments. Panca Mandiri Jaya Karawang. with sig $(0,000)<\alpha(0,05)$ and tcount $(14,104)>$ ttable $(1,655)$, then $\mathrm{HO}$ is replaced This is intended as a positive Work Discipline. Work Discipline contributes $409 \%$ to commitment.

Based on simultaneous considerations of Motivation and Work Discipline towards Commitments with criteria for test scores sig $(0,000)<\alpha(0.05)$ and $\mathrm{f}$ count (883K317)> t table (3.91), then H0 is rejected. Total Achievement Motivation (X1) and Work Discipline (X2) has a contribution to Commitment (Y) of 92.5\% while the remaining $7.5 \%$ is a contribution of other variables $(\varepsilon)$ that are not accepted. This shows that motivation and work discipline together have an interest in the commitment of CV employees. Panca Mandiri Jaya Karawang.
\end{abstract}

Keywords: Motivation, Work Discipline, Employee Commitment

\section{Pendahuluan}

Peranan sumber daya manusia dalam perusahaan sangatlah penting kerena sebagai penggerak utama seluruh kegiatan atau aktivitas perusahaan dalam mencapai tujuannya, baik untuk memperoleh keuntungan maupun untuk mempertahankan kelangsungan hidup perusahaan. Berhasil tidaknya suatu perusahaan dalam mempertahankan eksistensi perusahaan dimulai dari manusia itu sendiri dalam mempertahankan perusahaan. Dalam meningkatkan efektivitas 
dan efisiensi secara maksimal, khususnya tenaga kerja yang dimiliki untuk masa sekarang maupun masa yang akan datang perusahaan harus lebih kompetitif Masalah tenaga kerja merupakan salah satu masalah yang serius untuk mendapatkan perhatian. Karena keberhasilan suatu perusahaan tergantung pada baik buruknya tenaga kerja dalam melakukan pekerjaanya Pada hakekatnya kegiatan perusahaan merupakan upaya bersama antar pelaku dalam usaha tersebut yang diarahkan baik untuk pertumbuhan perusahaan maupun kesejahteraan masyarakat termasuk Pegawai. Seorang Pegawai dalam menjalankan pekerjaan pada suatu instansi atau organisasi mempunyai masalah yang sangat mendasar dimana seorang Pegawai yang satu dengan yang lain tidak akan sama tingkat Budaya Kerja yang dimiliki

Suatu Budaya Kerja organisasional menggambarkan ketertarikan seseorang dalam suatu organisasi. Budaya Kerja sendiri dapat merupakan tanggung jawab atau kemauan yang tinggi untuk menjalankan tugas atau pekerjaan. Setiap pimpinan pasti menginnginkan setiap anggotanya memiliki Budaya Kerja yang kuat terhadp organisasi, sebab Budaya Kerja yang tinggi, dapat menimbulakn kepatuhan atau kedisiplinan pada individu untuk mematuhi peraturan yang telah menjadi nilai atau budaya perusahaan. Selain Budaya Kerja, maka tinggi rendahnya kepatuhan Pegawai untuk mentaati segala peraturan perusahaan, juga ditentukan oleh motivasi kerja individu yang bersangkutan denga oraganisasi atau perusahaan.

Perusahaan jasa konstruksi sangat berperan dalam kegiatan perekonomian, khususnya dalam kegiatan pembangunan. Baik pembangunan sarana umum, pembangunan gedung maupun pembangunan lainnya. Dengan adanya industri jasa konstruksi akan memberikan peluang yang besar bagi penyerapan sumber daya manusia yang memiliki keahlian dibidang industri jasa konstruksi dan bangunan, dengan tersedianya lapangan pekerjaan maka akan menciptakan pendapatan bagi sumber daya manusia dan mengurangi tingkat pengangguran. Secara prospektif keberadaan industri jasa konstruksi baik skala kecil, menengah, maupun skala besar mempunyai nilai strategik bagi Indonesia, mengingat proporsi perannya cukup besar dan menyangkut banyaknya sumber daya manusia yang terlibat dalam kegiatan pelaksanaan suatu proyek dan pembangunanan.

\section{Perumusan Masalah}

Berdasarkan latar belakang yang di uraikan di atas, maka perumusan masalah adalah sebagai berikut :Bagaimana Motivasi Kerja Pegawai CV. Panca Mandiri Jaya Karawang. Bagaimana Disiplin kerja Pegawai CV. Panca Mandiri Jaya Karawang . Bagaimana Budaya Kerja Pegawai di CV. Panca Mandiri Jaya Karawang. Apakah terdapat Hubungan parsial Motivasi terhadap Budaya Kerja Pegawai CV. Panca Mandiri Jaya Karawang. Apakah terdapat Hubungan parsial Disiplin Kerja terhadap Budaya Kerja Pegawai CV. Panca Mandiri Jaya Karawangg. Apakah terdapat Hubungan simultan antara Motivasi dan Disiplin Kerja terhadap Budaya Kerja Pegawai di CV. Panca Mandiri Jaya Karawang . 


\section{Tinjauan pustaka}

Motivasi adalah suatu sugesti atau dorongan yang muncul karena diberikan oleh seseorang kepada orang lain atau diri sendiri. Dorongan itu dimaksudkan agar orang tersebut menjadi orang orang yang lebih baik dari yang sebelumnya. Motivasi juga dapat diartikan sebagai sebuah alasan yang mendasari sebuah perbuatan yang dilakukan seseorang.

Motivasi menurut Siagian (2009:102 ) merupakan daya dorong bagi seseorang untuk memberikan kontribusi yang sebesar mungkin demi keberhasilan organisasi mencapai tujuannya .

\section{Motivasi}

"Abraham maslow" mengemukakan bahwa Hirarki kebutuhan manusia adalah sebagai berikut :

a. Kebutuhan Fisiologis (Physiological-need)

Kebutuhan Fisiologis merupakan hirarki kebutuhan manusia yang paling dasar yang merupakan kebutuhan untuk dapat hidup seperti makan, minum, perumahan, oksigen, tidur dan sebagainya.

b. Kebutuhan rasa aman (safety need)

Apabila kebutuhan fisiologis relative sudah terpuaskan, maka muncul kebutuhan kedua yaitu kebutuhan akan rasa aman. Kebutuhan akan rasa aman ini meliputi keamanan akan perlindungan dari bahaya kecelakaan kerja, jaminan akan kelangsungan pekerjaannya dan jaminan akan hari tuanya pada saat mereka tidak lagi bekerja

c. Kebutuhan sosial (social-need)

Jika kebutuhan fisiologis dan rasa aman telah terpuaskan secara minimal, maka akan muncul kebutuhan sosial.Yaitu kebutuhan untuk persahabatan, afiliasi dana interaksi yang lebih erat dengan orang lain. Dalam organisasi akan berkaitan dengan kebutuhan akan adanya kelompok kerja yang kompak, supervise yang baik, rekreasi bersama dan sebagainya.

d. Kebutuhan penghargaan (Esteem-need)

Kebutuhan ini meliputi kebutuhan keinginan untuk dihormati, dihargai atas prestasi seseorang, pengakuan atas kemampuan dan keahlian seseorang serta efektifitas kerja seseorang.

e. Kebutuhan aktualisasi diri (self-actualization need)

Aktualisasi diri merupakan hirarki kebnutuhan dari Maslow yang paling tinggi. Aktualisasi diri berkaitan dengan proses pengembangan potensi yang sesungguhnya dari seseorang. Kebutuhan untuk menunjukkan kemampuan, keahlian dan potensi yang dimiliki seseorang. Kebutuhan aktualisasi diri ada kecenderungan potensinya yang meningkat karena orang mengaktualisasikan perilakunya.

\section{Pengertian Disiplin Kerja}

Disiplin merupakan salah satu fungsi manajemen sumber daya manusia Disiplin adalah kunci terwujunya tujuan perusahaan. 
adalah kesadaran dan kesediaan seseorang mentaati semua peraturan perusahaan dan norma-norma sosial yang berlaku. Kedisiplinan harus ditegakan dalam suatu organisasi perusahaan. Tanpa dukungan disiplin Pegawai yang baik, sulit bagi perusahaan untuk mewujudkan tujuannya. Jadi, kedisiplinan adalah kunci keberhasilan suatu perusahaan dalam mencapai tujuannya"

Kedisiplinan adalah tingkat kepatuhan dan ketaatan kepada aturan yang berlaku serta bersedia menerima sangsi atau hukuman jika melanggar aturan yang ditetapkan dalam kedisiplinan tersebut "Fahmi (2016: 75 )".

\section{Disiplin}

Bentuk disiplin yang baik akan tercemin pada suasana sebagai berikut "Sutrisno (2016:86)" :

a. "Tingginya rasa kepedulian Pegawai terhadap pencapaian tujuan perusahaan"

b. "Tingginya semangat dan gairah kerja dan inisiatif para Pegawai dalam melakukan pekerjaan".

c. "Besarnya rasa tanggung jawab para Pegawai untuk melaksanakan tugas dengn sebaik-baiknya".

d. "Berkembangnya rasa memiliki dan rasa solidaritas yang tinggi dikalangan Pegawai".

e. "Meningkatnya efisiensi dan produktivitas kerja para Pegawai".

\section{Pengertian Budaya Kerja}

Ada dua pendekatan dalam merumuskan definisi Budaya Kerja dalam berorganisasi. Pertama, melibatkan usaha untuk mengilustrasikan bahwa Budaya Kerja dapat muncul dalam berbagai bentuk. Maksudnya, arti dari Budaya Kerja menjelaskan perbedaan hubungan anggota organisasi dan entitas lainnya ( salah satunya organisasi itu sendiri). Kedua, melibatkan usaha untuk memisahkan di antara berbagai entitas tempat individu berkembang menjadi memiliki Budaya Kerja. Kedua pendekatan ini tidak compatible, namun dapat menjelaskan definisi Budaya Kerja, bagaimana proses perkembangannya, dan bagaimana implikasinya terhadap individu dan organisasi (Mayer \& Allen ) dalam Suhendi dan Anggara (2010).

Budaya Kerja Organisasional adalah derajat yang mana Pegawai percaya dan menerima tujuan-tujuan organisasi "Mathis dan Jackson dalam Sopiah (2008 : 155 )".

"Mayer dan Allen dalam Suhendi dan Anggara (2010 : 258)" mengatakan bahwa : Budaya Kerja dalam berorganisasi sebagai suatu konstruk psikologi yang merupakan karakteristik hubungan anggota organisasi dengan organisasinya dan memiliki implikasi terhadap keputusan individu untuk melanjutkan keanggotaannya dalam berorganisasi. berdasarkan, definisi tersebut anggota yang memiliki Budaya Kerja terhadap organisasinya akan lebih dapat bertahan sebagai bagian dari organisasi dibandingkan anggota yang tidak memiliki Budaya Kerja terhadap organisasi. 


\section{Metodologi penelitian}

\section{Desain Penelitian}

Metode penelitian pada dasarnya merupakan cara ilmiah untuk mendapatkan data dengan tujuan dan kegunaan tertentu. Cara ilmiah kegiatan penelitian itu didasarkan pada cirri-ciri keilmuan, yaitu rasional, empiris, dan sistematis ( Sugiyono, 2015:2). Pada penelitian ini menggunakan metode penelitian deskriptif dan verifikatif.

Metode deskriptif dilakukan untuk mengemukakan data yang masuk dengan cara dikelompokan dan ditabulasikan, kemudian hasilnya diberikan penjelasan. Metode deskriptif digunakan untuk mengetahui gambaran mengenai Motivasi, disiplin kerja dan Budaya Kerja Pegawai. Sedangkan penelitian verifikatif dilakukan untuk mengukur suatu fenomena penelitian dengan menggunakan alat bantu statistik. Adapun metode statistik yang digunakan untuk menganalisis hubungan antar variabel yang diteliti yaitu dengan menggunakan analisis jalur (Path analysis) untuk menguji Hubungan secara parsial/individu dan keseluruhan dan variabel bebas ( independent) terhadap variabel terkait (dependen)

\section{Variabel Penelitian}

Variabel penelitian adalah segala sesuatu yang berbentuk apa saja yang ditetapkan oleh peneliti untuk dipelajari sehingga diperoleh informasi tentang hal tersebut, kemudian ditarik kesimpulannya (Sugiyono, 2015 :38). Dalam penelitian ini terdapat variabel idependen (bebas) dan variabel dependen (terkait ). Variabel independen adalah variabel yang memHubungani atau yang menjadi sebab perubahannya atau timbulnya variabel dependen (Sugiyono, 2015: 39).

Variabel independen dalam penelitian ini yaitu Motivasi (X1) dan Disiplin Kerja (X2). Varabel dependen adalah variabel yang diHubungani atau yang menjadi akibat, karena adanya variabel bebas Variabel dependen dalam penelitian ini yaitu Budaya Kerja .

\section{Instrumen Penelitian}

Pada prinsipnya meneliti adalah melakukan pengukuran, maka harus ada alat ukur yang baik. Alat ukur salam penelitian tersebut disebut instrument penelitian. Jadi instrument penelitian adalah suatu alat yang digunakan untuk mengukur fenomena-fenomena alam maupun sosial yang diamati.

Secara spesifik fenomena itu disebut variabel penelitian (Emory,1985) dalam (Sugiyono 2015: 102).

Variabel penelitian merupakan konsep utama dari kajian yang diteliti. Untuk lebih jelasnya maka variabel harus disederhanakan dalam sub variabel atau dimensi kajian yang sesuai teori yang digunakan dlam penelitian. Selanjutnya variabel harus dapat diukur dengan indikator-indikator agar dapat terindentifikasi lebih detail sesuai teori dan kajian lapangan.

Jumlah instrument penelitian terhitung pada jumlah variabel penelitian yang telah ditetapkan untuk diteliti, seperti dalam penelitian kali ini " Hubungan Motivasi dan Disiplin kerja Terhadap Budaya Kerja Pegawai” adapun uraian lebih jelasnya dapat dilihat dalam tabel berikut:

\section{Tabel 1}


Data Variabel Penelitian

\begin{tabular}{|c|c|c|c|}
\hline Variabel & Sub Variabel & Indicator & $\begin{array}{c}\text { Pertanyaa } \\
n\end{array}$ \\
\hline \multirow{13}{*}{ Motivasi } & \multirow{3}{*}{ Kebutuhan Fisiologis } & Upah & 1 \\
\hline & & Istirahat/Hari libur & 2 \\
\hline & & Uang makan & 3 \\
\hline & \multirow{4}{*}{ Kebutuhan Rasa Aman } & jaminan kesehatan & 4 \\
\hline & & Jaminan kecelakaan & 5 \\
\hline & & Jaminan hari tua & 6 \\
\hline & & Fasilitas kerja & 7 \\
\hline & \multirow{2}{*}{ Kebutuhan Sosial } & Perhatian pemimpin & 8 \\
\hline & & Penempatan kerja & 9 \\
\hline & \multirow{2}{*}{ Kebutuhan Harga Diri } & Pengakuan & 10 \\
\hline & & Rekan kerja & 11 \\
\hline & \multirow[b]{2}{*}{$\begin{array}{c}\text { Kebutuhan Aktualisasi } \\
\text { Diri }\end{array}$} & Keinginan berprestasi & 12 \\
\hline & & $\begin{array}{l}\text { Keinginan } \\
\text { mengembangkan diri }\end{array}$ & 13 \\
\hline \multirow{13}{*}{$\begin{array}{l}\text { Disiplin } \\
\text { Kerja }\end{array}$} & \multirow{2}{*}{ Tujuan dan Kemampuan } & Sesuai Target & 1 \\
\hline & & Sesuai Standar & 2 \\
\hline & \multirow{2}{*}{ Teladan Pemimpin } & Pemimpin yang disiplin & 3 \\
\hline & & Kejujuran pemimpin & 4 \\
\hline & \multirow{2}{*}{ Keadilan } & Kebijakan & 5 \\
\hline & & Perlakuan yang sama & 6 \\
\hline & \multirow{3}{*}{ Waskat } & $\begin{array}{l}\text { Pengawasan perilaku dan } \\
\text { moral }\end{array}$ & 7 \\
\hline & & $\begin{array}{l}\text { Pengawasan sikap dan } \\
\text { gairah kerja }\end{array}$ & 8 \\
\hline & & $\begin{array}{l}\text { Pengawasan prestasi } \\
\text { kerja }\end{array}$ & 9 \\
\hline & sanksi hukuman & Pemberian Sanksi & 10 \\
\hline & Ketegasan & Pemimpin yang tegas & 11 \\
\hline & \multirow{2}{*}{ hubungan kemanusiaan } & Hubungan dengan atasan & 12 \\
\hline & & Hubungan dengan rekan & 13 \\
\hline
\end{tabular}

Tabel 2

Instrumen Penelitian

\begin{tabular}{|c|l|l|c|}
\hline Variabel & \multicolumn{1}{|c|}{ Sub variabel } & \multicolumn{1}{|c|}{ Indikator } & $\begin{array}{c}\text { Nomor } \\
\text { Pertanyaa } \\
\mathrm{n}\end{array}$ \\
\hline $\begin{array}{c}\text { Budaya } \\
\text { Kerja }\end{array}$ & Affective commitment & $\begin{array}{l}\text { Berangkat kerja penuh } \\
\text { semangat }\end{array}$ & 1 \\
\cline { 3 - 4 } & Loyalitas & 2 \\
\hline
\end{tabular}




\begin{tabular}{|c|c|c|}
\hline & $\begin{array}{l}\text { Mengutamakan } \\
\text { kepentingan organisasi }\end{array}$ & 3 \\
\hline & $\begin{array}{l}\text { Bekerja dengan kualitas } \\
\text { tinggi }\end{array}$ & 4 \\
\hline & $\begin{array}{l}\text { Mendalami pengetahuan } \\
\text { dan keterampilan }\end{array}$ & 5 \\
\hline \multirow{4}{*}{ Continuance commitment } & $\begin{array}{l}\text { Menerima jenis } \\
\text { pekerjaan yang } \\
\text { ditugaskan }\end{array}$ & 6 \\
\hline & $\begin{array}{l}\text { Perusahaan adalah yang } \\
\text { terbaik }\end{array}$ & 7 \\
\hline & $\begin{array}{l}\text { Kehidupan terganggu } \\
\text { jika keluar dari } \\
\text { perusahaan }\end{array}$ & 8 \\
\hline & $\begin{array}{l}\text { Banyak yang diperoleh } \\
\text { dalam bekerja }\end{array}$ & 9 \\
\hline \multirow{4}{*}{ Normative commitment } & Kemauan untuk bekerja & 10 \\
\hline & $\begin{array}{l}\text { Organisasi mendorong } \\
\text { bekerja sebaik mungkin }\end{array}$ & 11 \\
\hline & $\begin{array}{l}\text { Rasa hormat kepada } \\
\text { atasan dan rekan kerja }\end{array}$ & 12 \\
\hline & $\begin{array}{l}\text { Pemahaman terhadap } \\
\text { peraturan }\end{array}$ & 13 \\
\hline
\end{tabular}

Sumber : Fahmi (2016:101)

Hasibuan (2016 : 194 )

Mayer dan Allen dalam Suhendi \& Anggara (2010 259)

\section{Metode Pengumpulan Data}

Untuk mendapatkan data, peneliti menggunakan teknik pengumpulan data dengan cara :

Populasi , Sempel dan Teknik Sempling

Dengan menggunakan taraf kesalahan 5\%. Dengan menggunakan rumus Slovin. ( Buku Panduan Penulisan Skripsi Mahasiswa, 2017 : 28 ) sebagai berikut :

$$
\mathrm{n}=\frac{N}{N \cdot d^{2}+1}
$$

Dimana $\mathrm{n}=$ Ukuran Sampel

$\mathrm{N}=$ Ukuran Popula

$\mathrm{d}=$ galat pendugaan / standard deviasi

$\mathrm{n}=\frac{230}{230 \times 0.05^{2}+1}$

$$
=\frac{230}{1.575}
$$

$=146$

Berdasarkan populasi sebanyak 230 orang dan berdasarkan rumus di atas dengan menggunakan taraf kesalahan 5\% didapatkan sampel sebanyak 146 orang. 


\section{Teknik Pengumpulan Data}

Untuk menunjang penelitian maka diperlukan pengumpulan data, teori dan juga informasi yang sesuai, jelas dan mendukung agar dapat memberikan gambaran mengenai masalah yang sebenarnya. Oleh karena itu peneliti menggunakan pengumpulan data dengan cara:

1. Riset perpustakaan yaitu penelitian yang dilakukan dengan cara mempelajari buku-buku yang berhubungan dengan masalah yang dihadapi untuk mendukung analisis data yang diperlukan untuk skripsi ini.

2. Dalam pengumpulan data ini peneliti melakukan riset secara langsung pada objek penelitian untuk mendapatkan data yang diperlukan guna melengkapi data yang dibutuhkan yaitu dengan cara :

a. Observasi

Yaitu mengadakan penelitian secara langsung mengenai kegiatan yang dilaksanakan dan latar belakang keadaan sekarang yang berkaitan dengan masalah yang dihadapi.

b. Kuisoner

Yaitu teknik pengumpulan data yang dilakukan melalui daftar petanyaan yang dikirim kepada responden.

c. Wawancara :

Yaitu teknik pengumpulan data yang dilakukan secara terstruktur maupun tidak terstruktur, dan dilakukan melalui tatap muka ( face to face ) maupun menggunakan telpon atau $e$-mail.

Tabel 3

Skala Likert

\begin{tabular}{|l|c|}
\hline \multicolumn{1}{|c|}{ Pilihan Jawaban } & Bobot \\
\hline Sangat Setuju (SS) & 5 \\
\hline Setuju (S) & 4 \\
\hline Cukup Setuju (CS) & 3 \\
\hline Tidak Setuju (TS) & 2 \\
\hline Sangat Tidak Setuju (STS) & 1 \\
\hline
\end{tabular}

Sumber : Sugiyono $(2015: 93)$

\section{Uji Validitas}

Validitas menunjukan sejauh mana skor/nilai ukuran yang diperoleh benar-benar menyatakan hasil pengukuran/pengamatan. Validitas pada umumnya dipersalahkan berkaitan dengan hasil pengukuran psikologis atau nonfiik. Berkaitan dengan karakteristik psikologis, hasil pengukuran yang diperoleh sebenarnya diharapkan dengan menggambarkan atau memberikan skor/nilai suatu karakteristik lain yang menjadi perhatian utama. Macam validitas umumnya digolongkan dalam tiga kategori besar, yaitu validitas is ( conten validity), validitas konstruk dan validitas eksternal, untuk mengunjungi apakah pertanyaan-pertanyaan itu telah mengukur aspek yang sama digunakan validitas konstruk 
Cara mengukur validitas konstruk yaitu dengan mencari korelasi antara masing-masing pertanyaan dengan skor total menggunakan rumus teknik korelasi product moment, adapun dari perhitungan pengujian validitas konstruk menghasilkan koefisien korelasi diatas 0.30 maka dapat disimpulkan bahwa dari data yang diperoleh dari semua pertanyaan merupakan data yang valid, sedangkan koefisein korelasi dibawah 0.30 maka data yang diperoleh merupakan data yang tidak valid. (sugyono 2015: 125). Dan untuk menguji validitas ini menggunakan SPSS.

\section{Uji Reliabilitas}

Pengujian Reliabilitas dinyatakan dengan interval consistency dengan teknik belah dua ( split half) yang dianalisis dengan rumus spearman Brown ( split half), untuk keperluan tersebut maka butir-butir instrument dibelah dua menjadi dua kelompok, yaitu kelompok instrument ganjil dan genap, yang kemudian masingmasing dijumlahkan untuk mendapatkan skor total setiap kelompok, selanjutnya skor total setiap kelompok tersebut dicarikan korelasinya yang kemudian dimasukan kedalam rumus Spearman Brown dalam buku Sugiyono (2013: 131) sebagai berikut ;

Dimana :

$$
r i=\frac{2 \cdot r b}{1=r b}
$$

$\mathrm{ri}=$ rentabilits internal seluruh instrument

$\mathrm{rb}=$ korelasi product moment antara belahan pertama dan kedua.

Dengan kesimpulan yang reliabel memiliki nilai diatas 0.7 dan merupakan construct yang kuat. Ridwan (2010:118)

\section{Normalitas}

Menurut Sugyono dan Limakrisna dalam Narsih Narsiah (2015 : 125) bahwa uji normalitas data dimaksudkan untuk memperlihatkan bahwa data sampel berasal dari populasi yang berkontribusi normal. Uji normalitas bertujuan untuk mengetahui seberapa besar data berkontribusi secara normal dalam variabel penelitian ini. Data yang baik dapat digunakan dalam suatu penelitian yang berkontribusi secara normal.

Menurut Bahrul Kirom (2010 : 8) Uji Normalitas dapat dilakukan dengan melihat pada grafik distribusi normalitas serta dengan melakukan pengujian kolomogrov-smirnov, dengan pengujian sebagai berikut :

1. Angka signifikan (sig) $>0,05$ maka data terdistribusi normal

2. Angka signifikan (sig) $<0,05$ maka data tidak terdistribusi normal

Jika sebuah variabel memiliki sebaran data yang tidak terdistribusi secara normal, maka perlu dilakukan penyisihan data yang menyebabkan terjadinya ketidak normalan data. Pengujian ini menggunakan SPSS 16.

\section{Teknik Analisis Data}

Analisa yang data yang dimaksud adalah untuk menguji Hubungan Motivasi dan Disiplin Kerja terhadap Budaya Kerja pada Pegawai bagian departemen peralatan PT.Putra Bintang Sembada. Dalam penelitian ini menggunakan teknik Analisis Jalur. Ada tiga variabel yang akan diteliti, dua 
variabel bebas yaitu Motivasi (X1) dan Disiplin Kerja (X2) sedangkan variabel terkaitnya adalah Budaya Kerja Pegawai (Y).

Dalam penelitian ini untuk menganalisis data yang berasal dari hasil survei yang berasal dari pengukuran yaitu dengan menggunakan instrumen dari skala likert.

Formulasi Analisis Rentang Skala.

Rumus : $R S=\frac{n(m-1)}{m}$

Keterangan :

RS = Rentan Skala

$\mathrm{n}=$ Jumlah Sampel

$\mathrm{m}=$ Jumlah Alternatif Jawaban

Jika diasumsikan kepada rumus dengan jumlah sampel sebanyak ( ) maka RS dapat dihitung sebagai berikut :

Rentang skala (RS) sebesar :

$$
R S=\frac{146(5-1)}{5}=116.8
$$

Skala Terendah $=$ Skor Terendah $\mathrm{x}$ Jumlah Sampel

Skala Tertinggi $=$ Skor Tertinggi $\mathrm{x}$ Jumlah Sampel

1. Skala Penilaian tiap kriteria

Jumlah sampel 146 orang. Instrumen menggunakan skal likert pada skala terendah 1 dan skala tertinggi 5.

2. Perhitungan Skala

Diketahui $: \mathrm{n}=146$

$$
\mathrm{m} \quad=1 / 5
$$

Skala Terendah : Skor terendah x Jumlah sampel

$$
1 \times 146=146
$$

Skala Tertinggi : Skor tertinggi x jumlah sampel

$$
5 \times 146=730
$$

Rentang Skala $\quad: 146(5-1) / 5=116.8$

Tabel 4

Rentang Skala

\begin{tabular}{|c|c|c|c|c|}
\hline \multirow{2}{*}{$\begin{array}{c}\text { Skala } \\
\text { Skor }\end{array}$} & $\begin{array}{c}\text { Rentang } \\
\text { Skala }\end{array}$ & Motivasi & Disiplin Kerja & $\begin{array}{c}\text { Budaya Kerja } \\
\text { Pegawai }\end{array}$ \\
\cline { 3 - 5 } & $146-262.8$ & Sangat Setuju & Sangat Setuju & Sangat Setuju \\
\hline 2 & $\begin{array}{l}262.9- \\
379.6\end{array}$ & Setuju & Setuju & Setuju \\
\hline 3 & $\begin{array}{l}379.8- \\
496.4\end{array}$ & Cukup Setuju & Cukup Setuju & Cukup Setuju \\
\hline 4 & $\begin{array}{l}496.7- \\
613.2\end{array}$ & Tidak Setuju & Tidak Setuju & Tidak Setuju \\
\hline
\end{tabular}




\begin{tabular}{|c|c|c|c|c|}
5 & $613.3-730$ & $\begin{array}{c}\text { Sangat Tidak } \\
\text { Setuju }\end{array}$ & Sangat Tidak Setuju & $\begin{array}{c}\text { Sangat Tidak } \\
\text { Setuju }\end{array}$ \\
\hline
\end{tabular}

\section{Pembahasan}

Adapun pembahasan dari metode verifikatif dalam penelitian ini dapat diuraikan sebagai berikut :

1. Berdasarkan hasil penelitian menunjukan bahwa Budaya Kerja Pegawai pada Pegawai CV. Panca Mandiri Karawang, berdasarkan hasil kuesioner diperoleh nilai dengan rata-rata skor sebesar 489.923 , yang berada pada rentang skala 379,6 - 496,4 dengan kriteria Cukup Setuju. Artinya Budaya Kerja Pegawai CV. Panca Mandiri Jaya Karawang tinggi. Akan tetapi terdapat indikator yang memiliki nilai terendah yaitu organisasi mendorong bekerja sebaik mungkin dengan skor sebesar 464. Dan didapatkan nilai tetinggi yaitu mendalami pengetahuan dan keterampilan dengan skor tetinggi sebesar 520 .

2. Berdasarkan hasil penelitian menunjukan bahwa Motivasi pada Pegawai PT Putra Bintang Sembada berdasarkan hasil kuesioner diperoleh nilai dengan ratarata skor sebesar 493.461, yang berada pada rentang skala 496,4.- 613,2 dengan kriteria Cukup Setuju. artinya Motivasi Pegawai di CV. Panca Mandiri Jaya Karawang .cukup tinggi selain itu Pegawai mersa pemenuhan kebutuhan yang diberikan oleh perusahaan baik sehingga Pegawai termotivasi untuk bekerja. Akan tetapi masih terdapat indikator yang memiliki nilai terrendah yaitu kebutuhan istirahat /hari libur dengan skor sebesar 448. Sera didapatkan indikator yang memiliki nilai tertinggi yaitu keinginan berprestasi dengan skor sebesar 510.

3. Berdasarkan hasil penelitian menunjukan bahwa Disiplin Kerja pada Pegawai CV. Panca Mandiri Karawang berdasarkan hasil kuesioner diperoleh nilai dengan rata-rata skor sebesar 487.15 ,yang berada pada rentang skala 379,6 496,4 dengan kriteria Cukup Setuju, artinya Disiplin Kerja Pegawai CV. Panca Mandiri Jaya .cukup baik karena mereka bekerjai sesuai dengan peraturan dan prosedur perusahaan. Akan tetapi masih terdapat indikator yang memiliki nilai terrendah yaitu kesesuaian target dengan skor sebesar 459 dan terdapat indikator dengan nilai tertinggi yaitu kebijakan perusahaan dengan skor sebesar 520 .

4. Hubungan antara Motivasi dengan Disiplin Kerja memiliki nilai koefisien korelasi sebesar 0,721 dan mempunyai hubungan yang kuat dan searah karena nilainya positif. Hal ini menunjukan bahwa Motivasi Pegawai yang baik maka Disiplin kerja Pegawai pun akan baik.

5. Terdapat Hubungan dari Motivasi dan Disiplin Kerja terhadap Budaya Kerja Pegawai( dengan rincian sebagai berikut :

c. Terdapat Hubungan Parsial Motivasi terhadap Komitme Pegawai CV. Panca Mandiri Jaya Karawang .dengan nilai sig. $(0,000)<\alpha(0,05)$ dan $t_{\text {hitung }}$ $(17,266)>t_{\text {tabel }}(1,655)$, maka $\mathrm{H}_{0}$ ditolak dan Motivasi $\left(\mathrm{X}_{1}\right)$ memiliki kontribusi sebesar $51,7 \%$ terhadap Budaya Kerja Pegawai. Hal ini menunjukkan bahwan motivasi berHubungan positif atau dan signifikan terhadap Budaya Kerja Pegawai. 
d. Terdapat Hubungan Parsial Disiplin Kerja terhadap Budaya Kerja Pegawai CV. Panca Mandiri Jaya . dengan nilai sig. $(0,000)<\alpha(0,05)$ dan thitung $(14,104)>t_{\text {tabel }}(1,655)$, maka $\mathrm{H}_{0}$ ditolak dan Disiplin Kerja $\left(\mathrm{X}_{2}\right)$ memiliki kontribusi sebesar 40,9\% terhadap Budaya Kerja Pegawai. Hal ini menunjukkan bahwa Disiplin kerja berHubungan positif dan signifikan terhadap Budaya Kerja Pegawai.

6. Terdapat Hubungan simultan dari Motivasi dan Disiplin Kerja terhadap Budaya Kerja Pegawai dengan kriteria nilai uji nilai sig. $(0,000)<\alpha(0,05)$ dan $\mathrm{f}_{\text {hitung }}(883.317)>\mathrm{t}_{\text {tabel }}(3,91)$, maka $\mathrm{H}_{0}$ ditolak. Total Pengauh Motivasi $\left(\mathrm{X}_{1}\right)$ dan Disiplin Kerja $\left(\mathrm{X}_{2}\right)$ memiliki kontribusi terhadap Budaya Kerja Pegawai(Y) sebesar $92,5 \%$ sedangkan sisanya 7,5\% merupakan kontribusi variabel lain $(\varepsilon)$ yang tidak diteliti. Hal ini menunjukan bahwa motivasi dan disiplin kerja secara bersama-sama memiliki Hubungan terhadap Budaya Kerja Pegawai CV. Panca Mandiri Jaya Karwang. 


\section{Daftar Rujukan}

Anggara, H. S. (2010). Perilaku Organisasi. Bandung: Pustaka Setia.

Hasibuan. (2011). Manajemen Dasar, Pengertian, dsn Masalah. Jakarta: Bumi

Aksara

Bahrul,kirom. 2010. Mengukur kinerja pelayanan kepuasan konsumen. Bandung : Pustaka Reka Cipto

Kasmir. (2016). Manajemen Sumber Daya Manusia (Teori dan Praktek). Jakarta: Raja Grafindo Persada.

Kasmir. (2016). Manajemen Sumber Daya Manusia (Teori dan Praktek). Jakarta: Raja Grafindo Persada.

Hamli, A. Y. (2016). Manajemen Sumber Daya Manusia. Yogyakarta: CAPS center for academic publishing service).

Sugiyono. (2015). Metode Penelitian Kuantitatif Kualitatif dan R \& D. Bandung: Alfabeta.

Suwanto, T. Y. (2016). Manajemen Sumber Daya Manusia. Bandung: Alfabeta.

Sutrisno, E. (2016). Manajemen Sumber Daya Manusia. Jakarta: Kencana.

Mangkunegara, P. A. (2011). Manajemen Sumber Daya Manusia Perusahaan. Bandung: Remaja Rosdakarya.

Sedarmayanti. (2009). Sumber Daya Manusia dan Produktivitas Kerja. Bandung:

Mandar Maju. 